\title{
ラット切歯成熟期エナメル質の形成に及ぼす微小管阻害薬の 作用に関する研究
} 一エナメル質表層の GBHA 染色性に及ぼす作用について一 大谷 啓一*, 石毛 直美 ${ }^{*}$, 俣木 志朗**, 小椋 秀亮* 東京医科歯科大学歯学部歯科薬理学講座*, 長崎大学歯学部歯科薬理学講座**

(1993 年 7 月 16 日)

要約 : ラット切歯成熟期エナメル質表層のカルシウム動態におよぼす微小管阻害薬の作用を, glyoxal bis (2-hydroxyanil) (GBHA) 染色法を応用して検索した. ラットにコルヒチン（1.3 mg/ kg）を皮下注射 し経時的に屠殺し，切歯エナメル質表層を GBHA で染色し観察を行った．対照群ラットには同量の生理 食塩液を投与した，対照群のエナメル質表層では，GBHAにより赤色に染色された $4-5$ 本の縞状のバン ドが横走あるいは斜走して出現した. コルヒチン投与後, GBHAにより染色されたバンドの幅は広がり, その配列状態も乱れた. GBHA 染色領域のエナメル質表面に対する割合は, 対照群で約 $25 \%$ あっったが, コルヒチン投与後 8 ないし 24 時間で GBHA 染色領域の割合は約 $60 \%$ に拡大し最高に達した. 投与後 2 日以降この割合は減少し, 対照群と同程度に復したが, バンドの配列は乱れたままであった。 ルミコルヒ

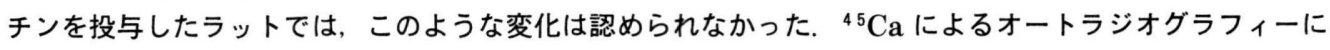
より対照群に見られた銀粒子の縞模様状の沈着パターンは, コルヒチン投与により消失し, 銀粒子はエナ メル質表層を一様にラベルしていた. 微小管阻害薬により生じる一過性の低カルシゥム血症の発現と, GBHA 染色領域の变化との関連を調べる目的で, サリチル酸ナトリゥム, フッ化ナトリウムなど, 低カ ルシウム血症を起す薬物を用いて観察を行ったところ，いずれの薬物も GBHA 染色像に変化をあたえな かった. したがって, 血漿カルシウム值の変動は, GBHA 染色領域の拡大と関連しなかった，以上の実 験結果より, コルヒチンなどの微小管阻害薬は, エナメル質表層のカルシゥム動態を示すと考えられる GBHA 染色領域に影響を与えることが明らかとなった，その作用は，エナメル芽細胞からェナメル質へ のカルシウム輸送機構, ならびにエナメル質の石灰化機構にかかわる微小管の機能が阻害された結果発現 したものと考えられた.

緒

言

エナメル質形成機構の研究によく用いられるラット切 歯の成熟期エナメル来細胞は, 細胞の遠心端の膜構造に 刷子縁を有する ruffle-ended ameloblast (RA) と, 比較的平坦な膜構造で構成される smooth-ended ameloblast (SA) と呼ばれる形態の著しく異なる2 種 類の細胞が存在し, エナメル質の石灰化にともなってこ れらの細胞が周期的に成熟期エナメル芽細胞層に現われ

${ }^{*}$ \%113 東京都文京区湯島 1-5-45

$* *$ T852 長崎市坂本町 $1-7-1$
ることが知られている(1〜6). glyoxal bis (2-hydroxyanil) (GBHA) 染色法は, キレート剤の一種である GBHA がカルシゥムイオンと結合すると Ca-GBHA の赤色の不溶性沈澱を形成することを利用し, 細胞内の カルシゥムイオンを組織化学的に検出することを目的に 開発された染色法である(7). この染色法を用いること により, ラット切歯成熟期エナメル質表層上を横走ある いは斜走する数本の赤色の染色帯が出現し, しかもこの 染色帯が SA の存在する領域と対応しており, SA の面 しているエナメル質の表層のカルシウムの性状が, 他の 部位と異なることが明らかにされている(8).したがっ て, エナメル芽細胞の周期的な形態変化にともない, エ 
ナメル質表層のカルシウムの性状も周期的に変化し, こ れが成熟期エナメル質の石灰化の進行に重要であること が指摘されている.

我々は従来より, 微小管阻害薬のエナメル質形成にお よぼす作用の研究を行い, コルヒチン投与によるエナメ ル芽細胞の分泌阻害作用の発現 $(9,10)$, ラット切歯工 ナメル質に特有の鉄沈着機構のコルヒチンによる障害作 用(11 13), エナメル質表層の GBHA により染色され る領域の割合がコルヒチン投与により拡大することなど を報告してきた(14)，今回，成熟期エナメル芽細胞に存 在する微小管の機能を解明する研究の一環として, 成熟 期エナメル質表層のカルシウム動態におよぼす微小管阻 害薬の影響を, GBHA 染色法と ${ }^{45} \mathrm{Ca}$ オートラジオグ ラフィーを用いて観察し, さらにこれら薬物により生じ る低カルシウム血症と, 表層カルシウムの変化の関連を 併せて検索した。

\section{実 験 方 法}

実験 1 : エナメル質表層の GBHA 染色領域におよぼす

\section{コルヒチンの作用}

平均体重約 $120 \mathrm{~g}$ の Wistar 系雄性ラット 60 匹を用 い1群 4-5匹として用い, 実験群には, コルヒチン （colchicine, Sigma, USA）を用量 $1.3 \mathrm{mg} / \mathrm{kg}$ になる ように背部皮下に注射し, 対照群には同量の生理食塩液 を投与した．実験群のラットは投与後 $2,4,8,24$ 時 間，2，3，6，12，24，36 日目にエ-テル麻酔下にて 断頭屠殺し, 対照群のラットは 8 時間後に屠殺した. 屠 殺後直ちに上下顎骨を摘出し, 切歯を顎骨より分離し, 湿ガーゼで切歯表面をぬぐいエナメル質表面を露出させ た後，GBHA 染色を行なった，GBHA 染色は， Takano ら(8) の方法に従い， $0.105 \mathrm{M}$ の NaOH を含 んだ $75 \%$ エタノール $2 \mathrm{ml} 20 \mathrm{mg}$ の GBHA (Fulka, Switzerland）を溶解し, 溶液がオレンジ色から赤色に 変化したところで切歯を浸漬し; 約 1 分間擋拌しながら 染色し, 染色終了後 100\%エ夕ノールで洗浄した. 観察 部位として, 分泌期エナメル芽細胞層直下の opaque boundary よりエナメル質に鉄が沈着開始する部位ま でを成熟エナメル質として，肉眼あるいは顕微鏡下にて 観察を行ない, 同時に写真撮影を行った。ささらに, エナ メル質表層の GBHA 染色領域の变化を定量的に解析す る目的で, 写真をトレースし, GBHAにより染色され た面積を自動画像解析装置（TAS Plus， Leica， Germany）を用いて計測し, 得られた值の成熟期エナ メル質表層の面積に対する比率を計算した.
実験 2： ${ }^{45} \mathrm{Ca}$ によるオートラジオグラフィーを用いた 検索

実験 1 の結果が, エナメル質のカルシウム輸送系の変 化を反映したものであるか否か確かめる目的で, ${ }^{4{ }^{5} \mathrm{Ca}}$ をトレーサーとしたオートラジオグラフィーによりエナ メル質の表層の変化を観察した。平均体重約 $130 \mathrm{~g}$ の Wistar 系雄性ラットを用い, 実験群のラットにはコル ヒチン（1.3 mg/ $\mathrm{kg}$, 皮下注）を投与し, 対照群のラッ トには生理食塩液を投与した. 薬物投与 8 時間後に, こ れらのラットはネンブタール麻酔下, ${ }^{4}{ }^{5} \mathrm{CaCl}_{2}$ (Amersham, England) を1.85 MBq 静脈内投与し, 10 分後に心臟より潅流固定 ( $2 \%$ グルタルアルデヒド) を施した. 固定終了後, 下顎切㐘を取り出しエナメル質 を露出し, 湿ガーゼにより表層をぬぐい, $37^{\circ} \mathrm{C}$ の恒温器 内にて乾燥した。 これらの切菌は, $10 \%$ ぶチン液に数 秒浸漬して歯の表層をコーティングし, 充分に乾燥した 後, オートラジオグラフィー用乳剤（Konika NR-M2, コニカ）を塗布した. 露出期間は 12 日とし, その後定 法に従い, 現像, 定着を行い, 切歯表層を観察した.

実験 3 : 薬物による低カルシウム血症とエナメル質表層 GBHA 染色領域の変化

コルヒチン投与後に発現する一過性の低カルシウム血 症 $(15,16)$ と, エナメル質表層 GBHA 染色像の変化 に関連があるか否か解明する目的で, 低カルシウム血症 を発現する薬物をラットに投与し実験 1 と同様の観察を 行った. 実験には平均体重約 $120 \mathrm{~g}$ のWistar 系雄性ラッ ト 40 匹を 1 群 $4-5$ 匹として用いた。薬物は微小管阻 害薬として, コルヒチン, ビンブラスチン (vinblastine, 塩野義製薬), 低カルシウム血症を生じる薬物としてサ リチル酸ナトリウム (sodium salicylate, 和光純薬工 業)(17), フッ化ナトリウム (sodium fluoride, 小宗 化学)(18）を用いた. コルヒチンは $1.3 \mathrm{mg} / \mathrm{kg}$ の用量 にて皮下注, ビンブラスチンは皮下注が出来ないため $2.0 \mathrm{mg} / \mathrm{kg}$ にて静注した. サリチル酸ナトリウムは 400 $\mathrm{mg} / \mathrm{kg}$, フッ化ナトリウムは $80 \mathrm{mg} / \mathrm{kg}$ の皮下注を行っ た. 屠殺時間はコルヒチン, ビンブラスチンは投与後 8 時間とし, サリチル酸ナトリウム, フッ化ナトリウムで は投与後 3 時間とした. いずれの薬物も予備実験を行い, 各薬物投与後の血症カルシウム值を経時的に測定し, 最 小值を示す時間を確認し, 投与量および投与後の屠殺時 間を決定した。

さらに観察された結果がコルヒチンの微小管阻害によ る特異的な作用か否かを検討する目的で, コルヒチンの 異性体であり, 微小管阻害作用を有していないルミコル 
ヒチン（lumicolchicine)(19）をコルヒチンと同用量 投与し検索を行なった。ルミコルヒチンは Hashimoto(11) の方法に従い, 95\%エタノールにコ ルヒチンを溶解し $(0.05 \%)$, 石英キュベット内で 3 時 間 $100 \mathrm{~W}$ の水銀ランプを照射した. 分光光度計を用い て $350 \mathrm{~nm}$ の吸光度の減少を計測し, ルミコルヒチンに 変化したことを確認した後, $40^{\circ} \mathrm{C}$ 水浴中でエ夕ノール を蒸発させ, ルミコルヒチンの粉末を得た.

採血はラットの屠殺時に, エーテル麻酔下で頝静脈よ りヘマトクリット管を用いて行ない, 原子吸光分光光度 計（Perkin Elmer, Model 603, USA）を用いて血漿 カルシウムの測定を行なった. また同時に, 上下顎切歯 のエナメル質表層を実験 1 と同様に GBHA にて染色し, 観察を行なった.

実験結果の統計的な解析は, Student's $t$-test により 行なった.

\section{実 験 結 果}

\section{1. エナメル質表層の GBHA 染色領域におよぼすコル} ヒチンの作用

対照群のラット切歯エナメル質では, GBHA により 赤色に染色された $4-5$ 本のバンドが縞状に出現し, エ ナメル質表面を横走あるいは斜走する像が観察され, 切 端側のバンドほよ゙より斜走する傾向が認められた。 また,
この縞状のバンドは左右の切歯でほぼ対称的に配列して いた（図 $1 \mathrm{a}$ ).コルヒチン投与後 2 時間では, 縞状に 存在する GBHA 染色領域は対照群とほぼ同様であり変 化は認められなかったが, 投与後 4 時間になると, GBHA に染色されたバンド状領域の幅が広がり始め, その配列状態も乱れ始めた. しかし, 縞状のバンドの数 には変化は見られなかった. 投与後 8 および 24 時間で GBHA 染色領域は著しく拡大し, その占める領域は最 大に達し, GBHAにより染色されない領域は縮小した (図 1 b).

画像解析装置により GBHA 染色領域の測定を行うと, 対照群の GBHA 染色領域は成熟期エナメル質表面の約 $25 \%$ 占めていたが, コルヒチン投与により染色領域は 拡大し，8ないし 24 時間後には成熟期エナメル質表面 の約 60\%を占めるようになった（図 2 ). 下顎切歯では, その増加は投与後 8 時間でピークに達し, 24 時間でも 同様であったが，上顎切歯では遅れて 24 時間でピーク に達した. コルヒチン投与後 2 日目よりこの拡大した GBHA 染色領域は減少し，3，6，12，24 日では, GBHA 染色領域の占める割合は対照群とほぼ同程度で あった. しかし, 縞状に配列するバンドは, 対照群で観 察されるような対称的な配列ではなく, その配列は乱れ 非対称的になり, 各バンドもエナメル質表層で途切れた り，またループ状を呈したりするなど，不連続な像が多

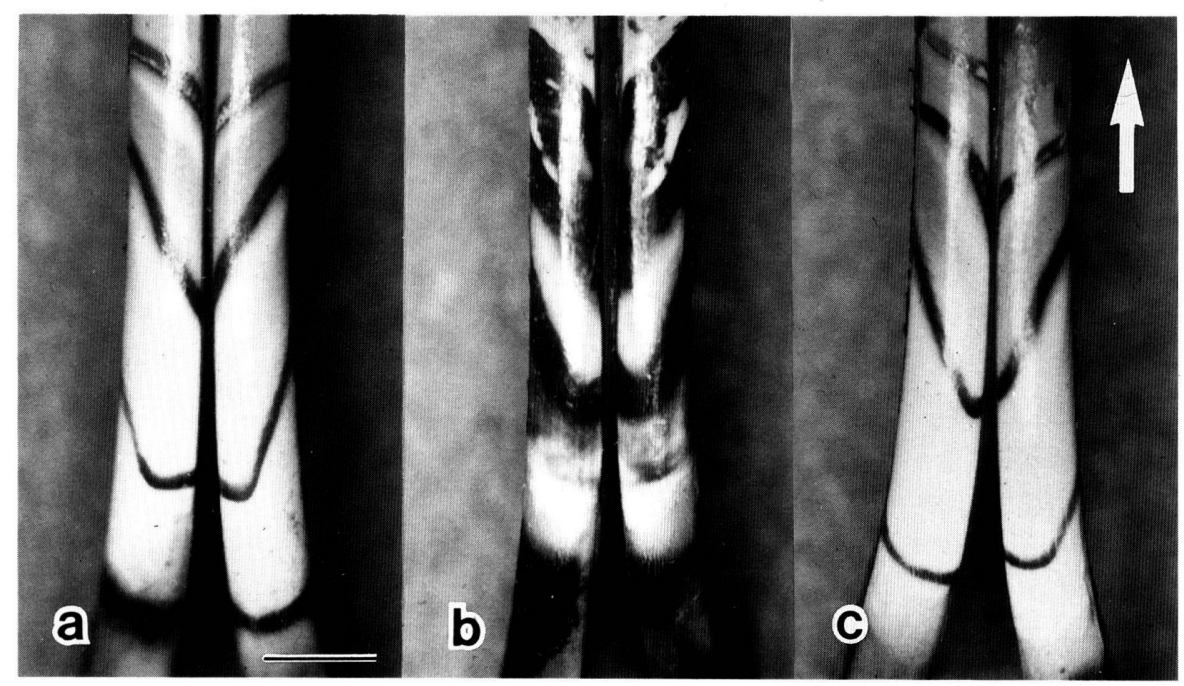

Fig. 1 Views of the labial surface of rat mandibular incisors. Stripes on the maturation enamel surface stained with GBHA. a) control, b) $8 \mathrm{hr}$ after the colchicine injection and c) $8 \mathrm{hr}$ after the lumicolchicine injection. The large arrow indicates the incisal direction. The bar represents $1 \mathrm{~mm}$. 


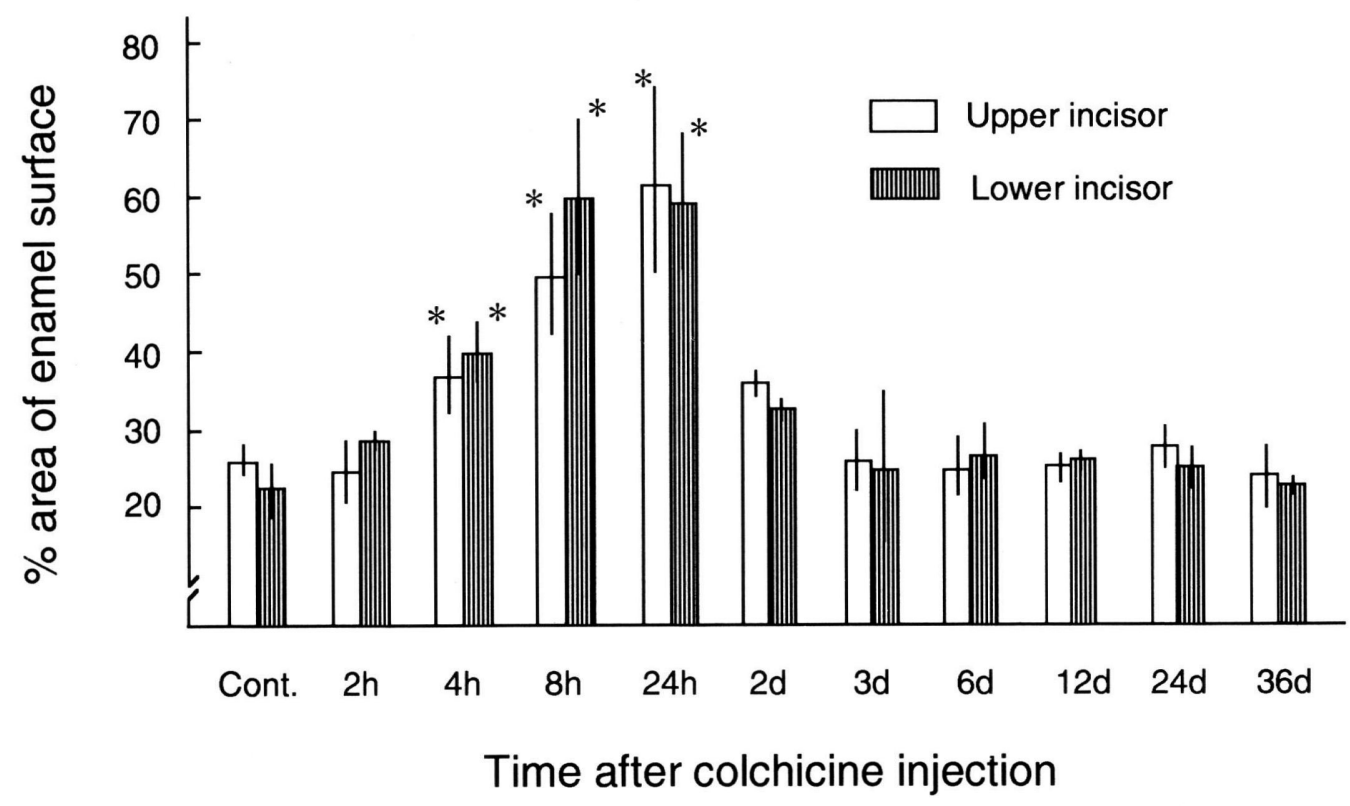

Fig. 2 Changes of the percent of GBHA staining area to the maturation enamel surface in upper and lower incisors after the colchicine injection. Values are expressed as the mean \pm S.D. $(n=4$ or 5$)$. * Significantly different from the controls, $\mathrm{P}<0.05$ or higher level of significance.

く認められた。 コルヒチン投与後 36 日では, GBHA 染色像は対照群とほぼ同様であった。

2. ${ }^{45} \mathrm{Ca}$ によるオートラジオグラフィーを用いた検索

${ }^{45} \mathrm{Ca}$ によるオートラジオグラフィーによる観察では, 対照群のラット切歯のエナメル質表層に数本の太い銀粒 子のバンドが存在し，その間は銀粒子の存在しない細い バンドにて区切られ, 縞模様を形成して存在した (図 $3 \mathrm{a}$ ). コルヒチン投与後 8 時間の観察では, ${ }^{45} \mathrm{Ca}$ による銀粒 子の縞模様状のバンドは消失し, 表層全体に銀粒子が観 察されたが，その分布は濃淡を示し一様ではなかった (図 3 b).

\section{3. 薬物による低カルシウム血症とエナメル質表層} GBHA 染色領域の変化

図 4 のグラフは, 薬物投与後の成熟期エナメル質表面 に対する GBHA 染色領域の比率と，同一時期における 血漿カルシウム值を示している. 血漿カルシウム值は対 照群で $11.00 \pm 0.46 \mathrm{mg} \%$ （平均土標準偏差, $\mathrm{N}=8$ ）で あるのに対し，コルヒチン，ビンブラスチン，サリチル 酸ナトリウム，フッ化ナトリウムを投与したラットで有 意なカルシゥム值の低下が観察された。しかし， GBHA 染色領域の比率の增加または配列の乱れは，コ
ルヒチン, ビンブラスチン投与ラットにのみ観察され， サリチル酸ナトリウム，フッ化ナトリウム投与ラットで は, その占める領域および配列に変化は認められなかっ た. 一方，ルミコルヒチン投与群では，血漿カルシウム 値, GBHA 染色像共に対照群と同様であった (図 $1 \mathrm{c}$ ).

\section{考察}

エナメル質の石灰化機構において，エナメル質成熟期 におけるカルシウムの輸送メカニズムは, リン酸カルシ ウム結晶（ハイドロキシアパタイト）の形成すなわち石 灰化に重要な役割を果たしている. 近年, 成熟期エナメ ル芽細胞には, SA, RA という2 種類の形態の細胞が 存在することが明らかとなり, 石灰化機構における物質 の移動や, カルシゥム輸送においてそれぞれ異なる機能 を果たしている可能性が示唆されている.オートラジオ グラフィーを用いた実験で, ${ }^{45} \mathrm{Ca}$ をレレーサーとして $\mathrm{SA}, \mathrm{RA}$ への取り込みを調べた結果では, エナメル質 への ${ }^{45} \mathrm{Ca}$ の取り込みは, 主に RA 領域の歯胚側より の限局された部位に観察され, 切歯全体としては数カ所 に取り込み部位が存在する $(20) .{ }^{45} \mathrm{Ca}$ 投与後 2 分以内 では, エナメル質表層のラベルされる領域はさらに狭い 


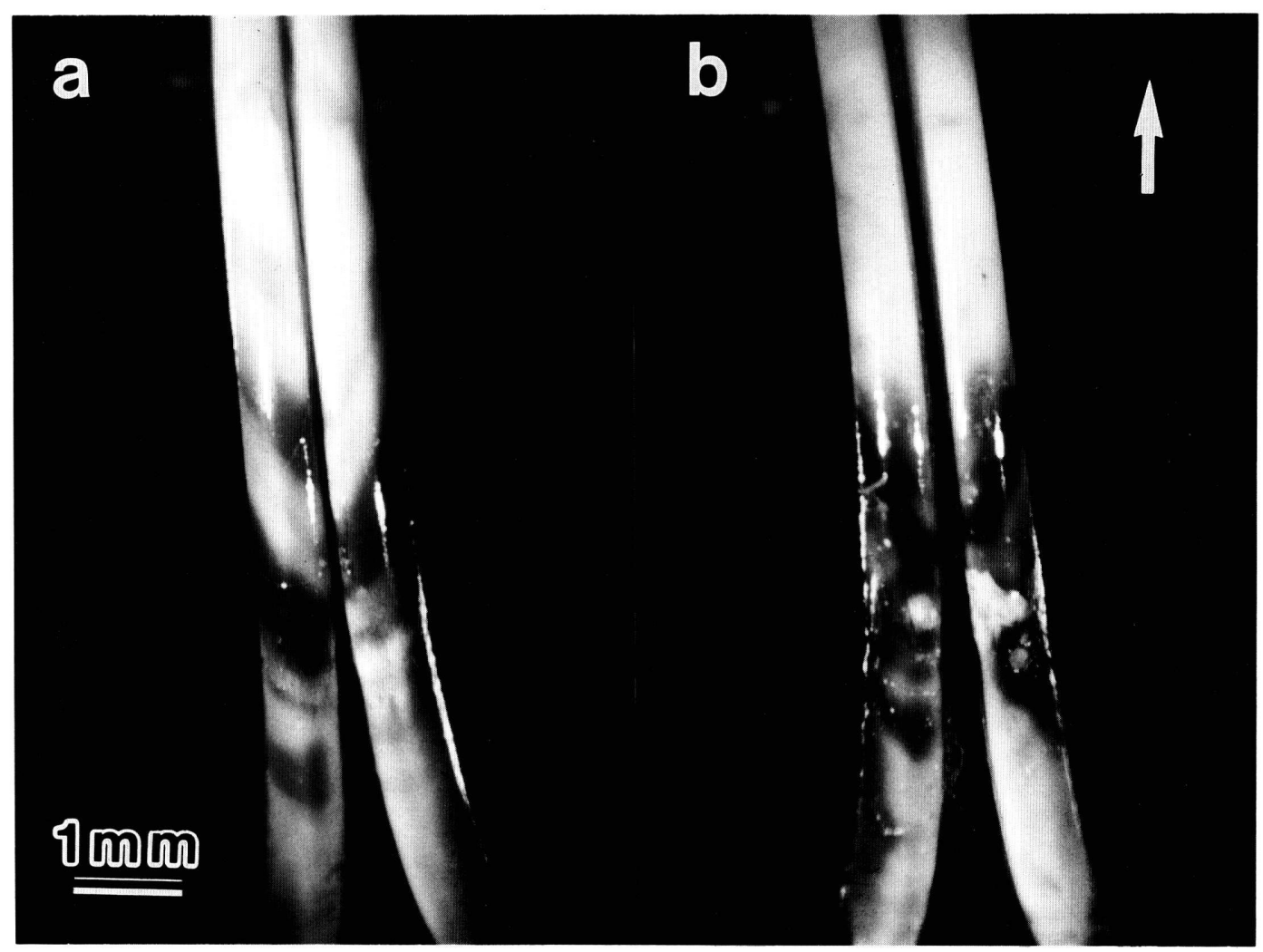

Fig. 3 Autoradiograph of the labial surface of rat mandibular incisor after ${ }^{45} \mathrm{Ca}$ injection. a) control and b) $8 \mathrm{hr}$ after the colchicine injection. ${ }^{45} \mathrm{Ca}$ labeling was observed as bands on the maturation enamel in control rats. Most of the ${ }^{45} \mathrm{Ca}$ reaction was disarranged after the colchicine injection. The large arrow indicates the incisal direction.

領域に限局される。このような ${ }^{45} \mathrm{Ca}$ のラベリングパター ンは, 本研究のオートラジオグラフィーの結果（図 3 ) においても観察することができた。 また，エナメル芽細 胞層からエナメル質への物質の流れを horseradish peroxidase を用いたトレーサー実験により検索すると, 物質の移動はRA の近心から細胞間を通り SA に至り, $\mathrm{SA}$ の遠心の物質の移動しやすい細胞間結合部を経てエ ナメル質表層に達することが明らかにされている(21). したがって, SA ではエナメル質との間に能動的な物質 の代謝はなく, 受動的な拡散のみで物質は移動し, RA 部では，エナメル質からの有機成分の脱却およびミネラ ルの添加が活発に行なわれていると推測されている(22). このような従来からの報告のみで, 成熟期エナメル質に おけるカルシウム輸送が, RA あるいはSAのいずれか が主体となり行なわれているのか断定することは出来な
いが， RA が物質の取り込みやカルシウム輸送機構に関 しては活発に機能し, SA は休止期状態にあるとする考 えが支配的である.

成熟期エナメル質表層の GBHA 染色領域が，SAの 領域に対応することは Takano ら（8）の報告により確 かめられているが, GBHA 染色性がエナメル質の性状 をどのように反映しているかに関しては明らかでない.

しかし, 貝殼の結晶（炭酸カルシウム）の場合につい ては, わずかに溶解傾向の高い結晶が GBHA に最も強 く染色され, 成長中の結晶が中等度の染色性を示すのに 対し, 安定状態の結晶はまったく染色されないことが指 摘されており (8), リン酸カルシウム結晶で成り立つエ ナメル質の GBHA 染色性も，おそらくこれに準じた結 晶状態を反映しているものと考えられる。つまり， GBHA に可染の SA 領域に対応するエナメル質表層部 


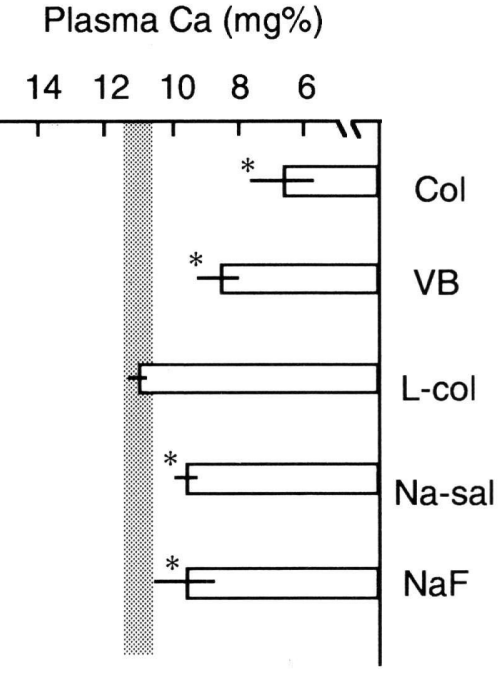

Control
$\%$ area of enamel surface

$2030 \quad 40 \quad 5060$

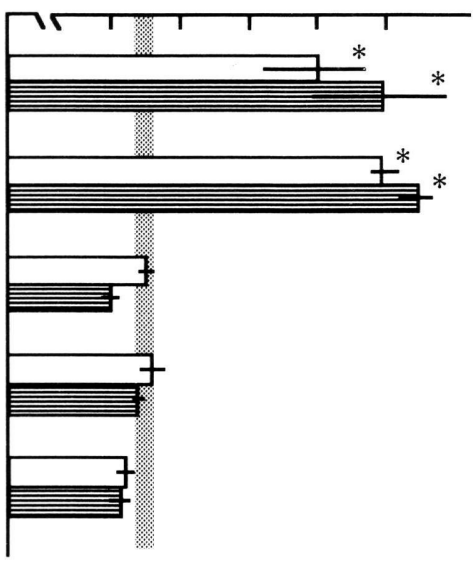

Upper incisor

Lower incisor

Fig. 4 Relationship between the plasma calcium level and the percent of GBHA staining area to the maturation enamel surface in upper and lower incisors. Shaded area represents the control value. Values are expressed as the mean \pm S.D. ( $\mathrm{n}=4$ or 5$)$. Col: colchicine $(1.3 \mathrm{mg} / \mathrm{kg}$, s.c.), VB: vinblastine $(2.0 \mathrm{mg} / \mathrm{kg}$, i.v.), L-col: lumicolchicine ( $1.3 \mathrm{mg} / \mathrm{kg}$, s.c.), Na-sal: sodium salicylate $(400 \mathrm{mg} / \mathrm{kg}$, s.c.), $\mathrm{NaF}$ : sodium fluoride $(80 \mathrm{mg} / \mathrm{kg}$, s.c.). * Significantly different from the controls, $\mathrm{P}<0.05$ or higher level of significance.

分のリン酸カルシウムは不安定な結晶状態で存在してお り,このような表層での結晶状態の変化は, エナメル芽 細胞の果たすカルシウムのエナメル質への輸送機構の变 化と, それに続いて起る周期的な石灰化の過程を間接的 に反映している思われる. また, エナメル芽細胞が RA から SA, SA から RA と周期的に形態変化を行うこと により，エナメル質表層の GBHA による縞模様状の染 色像が生じることが明らかにされている $(5,6,8)$. Sasaki ら (23) は牛の成熟期エナメル質を $\mathrm{pH}$ 指示薬 で染めたところ, 酸性部位と, 中性部位が交互に出現し, GBHAによる染色像と類似したパターンを示し, 中性 を示すェナメル質表層が GBHA により赤色に染まる部 位であることを明らかにした。このようなエナメル質の 表層の結晶部位での $\mathrm{pH}$ の周期的な変化も, エナメル質 の石灰化の進行と密接な関連を有していることが推測さ れている.

すでに Ishige(14) はコルヒチン投与により， ラット 切歯エナメル質表層の GBHA 染色領域あるいはカルセ インのラベリング領域が増大し, その縞模様が乱れる現
象を報告し, 微小管の破壊が, 成熟期エナメル芽細胞の 周期的な形態変化を阻害するのではないかと推察した. 本研究で観察されたコルヒチン投与後 8 及び 24 時間に おける GBHA 染色領域の増加も, この報告と一致した あのであった，先に述べたように，エナメル質表層の GBHA 染色像は, エナメル芽細胞の形態变化にともな い起るエナメル質の石灰化の周期的な進行を示している と考えられることから, 本研究の結果は, コルヒチンに よる微小管の破壊が, エナメル芽細胞におけるカルシウ ム輸送機構ならびに成熟期エナメル質の石灰化の進行に なんらかの重大な変化を引き起こしたことを示すすのと 思われる。

微小管は不偏的な細胞小器官として広く細胞に分布し, 細胞骨格として物質の輸送, 分泌, 分裂時の紡錐系, 細 胞膜の裏打ち, 各受容体の制御機構等に関与している. エナメル芽細胞においても微小管は細胞骨格として, エ ナメル質の石灰化に伴う細胞機能発現に重要な役割を果 たしていると考えられているが, その詳細は明らかでな い. コルヒチン, ビンブラスチン, ビンクリスチン等は, 
特異的に微小管を阻害し，その機能を障害することから, 微小管阻害薬として知られている(24). Akita ら (25) は, コルヒチン, ビンブラスチン投与後の成熟期エナメ ル芽細胞を光学, 電子顕微鏡を用いて観察し, 薬物投与 後 8 時間以内に微小管数が減少し, RA の ruffling が 著明に変化，消失し，さらに RA の遠位細胞間結合が 開裂してしまうこともあると報告している，沢田(26) は, ビンブラスチン, ビンクリスチンをラットに投与し, 基質形成期エナメル芽細胞の形態学的変化を経時的に観 察し, 細胞間に程度の差はあるが, 投与後 3 及び 6 時間 で微小管は激減するが, 投与後 24 時間になると細胞内 各所に細胞長軸に平行に走行しながら分布する微小管が 観察され, 薬物投与後の時間の経過とともに回復傾向に 向かうことを示している. また, Ogura ら $(9,27)$ は, コルヒチン投与により, エナメル芽細胞内の細胞小器官 の分布の乱れと, RA 近心の刷子縁 (ruffled border) が破壊する現象を報告している. また最近，コルヒチン， ビンブラスチンの投与により成熟期エナメル牙細胞の $\mathrm{RA}$ の刷子縁の消失が起り, その際にカルシウム輸送機 構に障害が起きている可能性が, ピロアンチモン酸によ る組織化学的所見をもとに報告された $(28,29)$. 本研究 の ${ }^{45} \mathrm{Ca}$ を用いたオートラジオグラフィーにおいても，

${ }^{45} \mathrm{Ca}$ のエナメル質表層への取り込みがコルヒチンによ り変化し, 縞状の銀粒子の沈着パターンが消失し, 表層 全体に銀粒子が観察されたことから，コルヒチン投与に よるエナメル芽細胞の微小管の破壊作用により, エナメ ル芽細胞の行っているカルシウム輸送機構に変動が起き, その結果, GBHA 染色領域の増加ならびに ${ }^{45} \mathrm{Ca}$ の銀 粒子の沈着パターンの乱れが起きたものと思われる. ま た，微小管の破壊作用を持たないルミコルヒチン投与に より GBHA 染色性に影響が見られなかったことから， 微小管への特異的な破壊作用がこの現象に関連している ことが裏付けられた。 したがって，エナメル牙細胞の微 小管は, 細胞骨格としてカルシウム輸送機構と, それに 続いて起るエナメル質の石灰化の進行に重要な役割を果 たしているものと思われる。しかし，エナメル芽細胞に よるエナメル質の石灰化には, カルシウム輸送以外に, 有機性基質の脱却など，別の細胞機能が関与しており， 微小管の破壊がこれらの機能に影響を及ぼしている可能 性も考えられる. 今後, この点からの検討も必要であろ う.

コルヒチン投与による GBHA 染色領域の拡大のピー クは, 下顎切歯で投与後 8 時間, 上顎切歯で 24 時間と 時間的な差が見られた。この差の原因は不明であるが，
一つの理由として, エナメル芽細胞の周期的な形態変化 のサイクルが, 上下顎切歯で異なる $(5,6)$ ことが薬物 作用の発現に影響し, その結果, GBHA 染色による縞 模様の形態の乱れに差が生じた可能性が考えられる. ま た, 投与後 24 時間以降, GBHA 染色の領域の拡大は 減少し, 対照群のレベルに戻っていたが, これは薬物の 作用からの回復状態を示すむのと考えられる. しかし, このような場合にも縞模様のパターンは乱れたままであっ たことから, 個々のエナメル芽細胞の周期的な形態変化 は正常であっても, 細胞の配列の乱れが依然として残っ ているものと考えられる.

コルヒチンなどの微小管阻害薬を投与すると, 血漿力 ルシウム值の急速な低下と速やかな回復現象が報告され ている $(15,16)$. 従って, この低カルシウム血症が, エ ナメル質表層のリン酸カルシウム結晶の性状に影響を与 えて, GBHA 染色領域の拡大が生じた可能性が考えら れた. しかし, GBHA 染色像の経時的な変化と, 血漿 カルシウム值の变動の関連性を検索してみた結果, 血漿 カルシウム值の変動と GBHA 染色像の変化の両者がと あに発現する場合は, コルヒチン, ビンブラスチンを投 与した時のみであり, 他の薬物の投与では GBHA 染色 像に变化が見られなかった（図 4 ). 従って, GBHA 染色によって観察されるエナメル質表面の性状の变化と, 血漿カルシウム值の変動は直接的な関連はなく, この現 象が微小管阻害薬に特有のものであることが示唆された. また, 微小管阻害薬以外の薬物により発現した実験的な 低カルシウム血症状態において, GBHA 染色性に変化 が生じなかった事実は, エナメル牙細胞のカルシウム輸 送機構, あるいは石灰化に伴うエナメル質表層の結晶の 性状変化が, 全身的なカルシウム恒常性の乱れにほ之ん よ゙影響されないことを示しており, エナメル質の石灰化 機構を考える上で重要な所見であると思われる.

以上述べた本実験の結果より, コルヒチン投与による 成熟期エナメル質表層の GBHA 染色像の変化は, 細胞 骨格として機能しているエナメル芽細胞の微小管がこれ ら薬物により阻害され, その結果, 能動的なあるいは受 動的なカルシウムの輸送系に変化が生じ, 引き続いて起 るエナメル質の石灰化の過程に変化が生じたことにより 発現するあのと思われる. したがって, エナメル質の石 灰化に伴うエナメル芽細胞の機能発現に, 微小管は重要 な役割を果たしている可能性が示唆された. 


\section{文献}

1) Suga, S.: Amelogenesis: Some histological and histochemical observations. Int. Dent. J. 9, 394 426 (1959)

2) Warshawsky, H. and Smith, C.E.: Morphological calcification of rat incisor ameloblasts. Anat. Rec. 179, 423 446 (1974)

3) Josephsen, K. and Fejerskov, 0.: Ameloblast modulation in the maturation zone of the rat incisor enamel organ. A light and electron microscopic study. J. Anat. 124, 45 70 (1977)

4) Takano, Y. and Ozawa, H.: Ultrastructural and cytochemical observations on the alternating morphologic changes of the ameloblasts at the stage of enamel maturation. Arch. Histol. Japan. 43, 385 399 (1980)

5) Ishige, N., Ohya, K. and Ogura, H.: A rapid cyclic modulation of ameloblasts during enamel maturation. J. Dent. Res. 65, 354 (1987)

6) Smith, C.E., McKee, M.D. and Nanci, A.: Cyclic induction and rapid movement of sequential waves of new smooth-ended ameloblast modulation bands in rat incisors as visualized by polychrome fluorescent labeling and GBHA-staining of maturing enamel. Adv. Dent. Res. 1, 162 175 (1987)

7) Kashiwa, H.K. and Atkinson, W.B.: The applicability of a new schiff base, glyoxal bis (2-hydroxyanil), for the cytochemical localization of ionic calcium. J. Histochem. Cytochem. 11, 258 264 (1963)

8) Takano, Y., Crenshaw, M.A., Bawden, J.W., Hammarstrom, L. and Lindskog, S.: The visualization of the patterns of ameloblast modulation by the glyoxal bis (2-hydroxyanil) staining method. J. Dent. Res. 61, 1580 1586 (1982)

9) Ogura, H., Kudo, N. and Lin, W.L. : Inhibitory action of colchicine on the secretory function of matrix formative cells in hard tissues. Japan. J. Pharmacol. 26, 82P (1976)

10) Kudo, N.: Effect of colchicine on the secretion of matrices of dentine and enamel in the rat incisor: An autoradiographic study using $\left[{ }^{3} \mathrm{H}\right]$-proline. Calcif Tissue Res. 18, 37 46 (1975)

11) Hashimoto, K.: The effect of colchicine on the pigmentation of the enamel surface in rat incisors. Bull. Tokyo Med. Dent. Univ. 31, 115 126 (1984)

12) Kubota, M., Ohya, K. and Ogura, H.: Effect of colchicine on iron transport during stage of maturation and enamel pigmentation in rat incisor: An autoradiographic study using ${ }^{55} \mathrm{Fe}$. Adv. Dent. Res. 1, 330 338 (1987)

13) Yasui, M.: Inhibitory effect of colchicine on the iron transport and the release system in rat incisor ameloblasts: An ultrastructural study. Japan. J. Oral Biol. 32, 440 459 (1990)

14) Ishige, N.: Effect of colchicine on the pattern of ameloblast modulation visualized by the glyoxal bis (2-hydroxyanil) staining and calcein labeling in rat incisor. Japan. J. Oral Biol. 29, 107 116 (1987)

15) Heath, D.A., Palmer, J.S. and Aurbach, G.D.: The hypocalcemic action of colchicine. Endo-crinology 90, 1589 1593 (1972)

16) Ohya, K. and Ogura, H.: The effect of colchicine or vinblastine on the blood calcium level in rats. Eur. J. Pharmacol. 248, 111 119 (1993)

17）加藤有三，小椋秀亮：実験的異所性石灰化現象にお よぼす非ステロイド性抗炎症薬の影響。骨代謝 14 , 29〜34 (1981)

18）松本昌世：象牙質の縞模様と血液組成との関係. 腔病会誌 26, 1723 1742（1959）

19) Wilson, L. and Friedkin, M.: The biochemical events of mitosis. II . The in vivo and in vitro binding of colchicine in grasshopper embryos and its possible relation to inhibition of mitosis. Biochemistry 6, 3126 3135 (1967)

20) Reith, E.J., Schmid, M.I. and Boyde, A.: Rapid uptake of calcium in maturing enamel of the rat incisor. Histochemistry 80, 409 410 (1984)

21) Takano, Y. and Ozawa, H.: Autoradiographic and tracer experiments to the exit route for the resorbed organic matrix of the enamel at the stage of maturation. In Tooth Enamel IV, Edited by Fearnhead, R.W. and Suga, S., pp.1580 1587, Elsevier Sci. Publ. Co., Amsterdam (1984)

22) Crenshaw, M. and Takano, Y.: Mechanisms by which the enamel organ controls calcium entry into developing enamel. J. Dent. Res. 61, 1574 1579 (1982)

23) Sasaki, S., Takagi, T. and Suzuki, M.: Cyclical changes in $\mathrm{pH}$ in bovine developing enamel as sequential bands. Arch. Oral Biol. 36, 227 231 (1991)

24) Dustin, P.: Microtubule poisons. In Microtubules, Edited by Dustin, P., pp.171 233, Springer Verlag, Berlin (1984)

25) Akita, H., Kagayama, M. and Sato, R.: Light and electron microscopy of the effects of colchicine and vinblastine on maturing rat ameloblasts in vivo. Arch. Oral Biol. 28, 263 271 (1983)

26）沢田 隆：ビンクリスチンとビンブラスチン投与に よるラット珐瑯芽細胞超微構造の変化. 歯科学報 82, 347 383 (1982)

27) Ogura, H., Ohya, K., Hashimoto, K. and Kubota, M.: Experimental studies on the transport mechanism of iron in rat incisors using ${ }^{55} \mathrm{Fe}$ and colchicine. In Tooth Enamel IV, Edited by Fearnhead, R.W. and Suga, S., pp.256 260, 
Elsevier Sci. Publ. Co., Amsterdam (1984)

28) Eisenmann, D.R., Salama, A.H., Zaki, A.M.E. and Ashrafi, S.H.: Cytochemical localization of calcium and $\mathrm{Ca}^{2+}, \mathrm{Mg}^{2+}$-adenosine triphosphatase in colchicine-altered rat incisor ameloblasts. J. Histochem. Cytochem. 38, 1469 1478 (1990)
29) Eisenmann, D.R., Salama, A.H. and Zaki, A.M.E.: Effects of vinblastine on calcium distribution pattern and $\mathrm{Ca}^{2+}, \mathrm{Mg}^{2+}$-adenosine triphosphatase in rat incisor maturation ameloblasts. J. Histochem. Cytochem. 40, 143 151 (1992)

Abstract-Effects of microtubule inhibitors on the amelogenesis in rat incisor enamel at the maturation stage: Changes of staining patterns of GBHA on the enamel surface. Keiichi OHYA, Naomi ISHIGE, Shiro MATAKI* and Hideaki OGURA (Department of Pharmacology, Faculty of Dentistry, Tokyo Medical and Dental University, 1-5-45 Yushima, Bunkyo-ku, Tokyo 113, Japan and *Department of Pharmacology, Nagasaki University School of Dentistry, 1-7-1 Sakamoto, Nagasaki 852, Japan).

Folia pharmacol. japon. 102, 323 331 (1993)

We investigated the effect of microtubule inhibitors on the amelogenesis in rat incisor enamel at the maturation stage by the glyoxal bis (2-hydroxyanil) (GBHA) staining method. Several red stripes stained with GBHA appeared on the maturation enamel surface of control rats. Colchicine injection $(1.3 \mathrm{mg} / \mathrm{kg}$, s.c.) disarranged the GBHA staining stripes and increased the staining area. The ratio of the GBHA staining area to the maturation enamel surface was about $25 \%$ in the control, but this value increased about $60 \%$ at 8 and 24 $\mathrm{hr}$ after the colchicine injection. Lumicolchicine, which does not have the ability to disrupt microtubules, did not cause any significant changes in the enamel surface. The incorporation of ${ }^{45} \mathrm{Ca}$ to the maturation enamel was also reduced by colchicine. Since the hypocalcemic action of microtubule inhibitors may be related to the change of the enamel surface, other drugs, sodium salicylate and sodium fluoride, that have a hypocalcemic action were tested. The staining pattern was not altered by these drugs. Therefore, the hypocalcemic action was independent of the changes of the GBHA staining pattern. These results indicated that the disruption of microtubules in the ameloblasts inhibited calcium movement in the maturation enamel, resulting in the disarrangement of the GBHA staining pattern. 